\title{
THE IMPACT OF IDEA MANAGEMENT SYSTEMS ON INTELLECTUAL RESOURCES DEVELOPMENT
}

\author{
Elīna Miḳelsone \\ BA School of Business and Finance, Latvia \\ Tatjana Volkova \\ BA School of Business and Finance, Latvia \\ Aivars Spilbergs \\ BA School of Business and Finance, Latvia \\ Elita Lielā \\ BA School of Business and Finance, Latvia
}

\begin{abstract}
Topicality/Problem. Idea management systems (IMS) are manageable, systematic tools, tool kits or complex systems that helps to generate and evaluate ideas and are an important element of organizational development. Many well-known organizations (e.g. Volkswagen, Microsoft, GE Healthcare, Procter and Gamble, Boeing, Siemens, etc) are successfully applying web-based IMS. But there is no research that explores the impact of webbased IMS on intellectual resources development.

Research aim - to research the impact of IMS on intellectual resources development and to provide recommendations to practitioners for its broader assistance in enterprises to ensure innovation acceleration.

Methodological approach. The empirical research was based on 447 enterprise survey applying.

The research results show the following results: IMS application has resulted in a new intellectual resource, in a patents and improved innovation acceleration.

Research limitations. Survey research may limit the generalisability of the result, because the survey target group is commercially available web-based IMS applied enterprises.

Originality/value. The research based on the empirical data analysis contributes to understanding the directions and significance of IMS impact on intellectual resources development.
\end{abstract}

Keywords: idea management systems, innovation acceleration, intellectual resources, patents, survey research.

\section{Introduction}

The development of intellectual resources for delivering innovations attracted research interests from many scholars (Chesbrough, 2006; Dahlander \& Gann, 2010; Gassmann, Enkel \& Chesbrough, 2010; West \& Bogers, 2014; 
Chesbrough, Lettl, \& Ritter, 2018; Luyu, Zhu, Han, He, \& Bao, 2020; Guertlerab \& Sick, 2020; Zhilenkova, Budanova, Bulkhov, \& Rodionov, 2019).

IMS are manageable, systematic tools, tool kits or complex systems that helps to generate and evaluate ideas and are an important element of organizational development. Many well-known organizations (e.g. Volkswagen, Microsoft, GE Healthcare, Procter and Gamble, Boeing, Siemens, etc) are successfully applying web-based IMS. But there is no research that explores the impact of web-based IMS on intellectual resources development.

There is a gap in literature to identify the role of Idea management system (IMS) to develop intellectual resources and specifically generate patents, as well to deliver innovations. Research aim - to research the impact of IMS on intellectual resources development and to provide recommendations to practitioners for its broader assistance in enterprises to ensure innovation acceleration.

To reach the aim was conducted the survey about IMS and it's application. It should be noted that in order to reach the target audience more accurately, the authors asked IMS developers to distribute the survey to their clients. The empirical research was based on 447 enterprise survey applying.

\section{Characteristics of Idea Management and Idea Management Systems}

To explore concept of IMS it is important to study also idea management, because reveals social elements of these systems (Selart \& Johansen, 2011), structural process elements (Deichmann, 2012; Westerski, 2013). IM studies mainly explores these elements based on the real case studies and existing commercially available IMS has (Westerski, Dalamagas, \& Iglesias, 2013; Bertetta, 2015), but also a lot of studies tries to explotre these elements by creating new IMS (Bothos, Apostoulou, \& Mantzas, 2012; Lowe \& Heller, 2014).

Table 1 IM and IMS Main Characteristics (Miḳelsone, Volkova, \& Liela, 2019)

IM - systematic, manageable process of idea generation, evaluation and further process continuation

IM dimensions

Idea generation (preparation, Idea evaluation (screening, capture/gathering of ideas, selection, retention)

Further IM (further concept retention, enhancement) development with IM iterations, distribution of ideas, retention)

IMS - a tool, tool kit or complex system which provides systematic, the manageable process of idea generation, evaluation and further IM. 
The article describes only commercially available web-based IMS application and IMS impact on the performance results - focus has been selected as a narrowing point in order to better identify the sample of the study. See diferences between idea management (IM) and IMS in Table 1.

The studies of the relationships between IMS and intellectual resources, IMS and patents become even more important in a fast-changing environment as it is a determinant of competitiveness for established firms to achieve a good performance in the long-term. The same applies to the studies of usage of IMS and capability to deliver innovations relationship.

Involved IMS sources could define 3 main IMS types (external, internal or mixed IMS). Main criteria for this classification is where are the obtained knowledge used in the IM internally or externally of the organisation. Internal IMS involve in IM all employees of the organisation or only some departments. External IMS - crowds, loyal clients etc. Mixed IMS provides a opportunity to involve both- internal and external idea generators and evaluators.

\section{The Linkage between Intellectual Resources and Intellectual Capital}

According to O'Cass and Sok intellectual resources include intangible assets such as licences, trade marks and patents held by the enterprises (O'Cass \& Sok, 2013).

In the literature, most studies explores evidence for the tight link between intellectual capital (IC) and innovation performance of an organization (European Commission, 2006; Inkinen, Kianto, Vanhala, \& Ritala, 2014; Lerro, Linzalone, \& Schiuma, 2014; Subramaniam \& Youndt, 2005; Teece, 2007; Dumay, Rooney, \& Marini, 2013). The IC concept was introduced by Galbraith (Galbraith, 1969). Edvinsson and Malone explored that IC is the set of intangible assets that the enterprise owns or has access to (Edvinsson \& Malone, 1997).

Belluci et al states that IC proved itself to be a very versatile, dynamic and contemporary concept, capable to raise an increasing scholar interest year by year and to renew itself (Belluci, Marzi, Orlando, \& Ciampi, 2020).

The authors of the paper agree with M. Buenechea-Elberdin (2017) that comprehending what is known about the IC and innovation relationship is significant for both academics, aiming to grasp potential research opportunities, and managers, looking for insights into how to enforce innovation in their organisations.

Warkentin states that IC emerges from the difference between the book value and the market value. So, if a firm has this mismatch that means it has a great future potential. Although it is not so clear where does it comes from? From the intelligence, $[. .$.$] the collaboration between people. [...] So, how do firm create$ 
knowledge, IC? How they grow it, foster it, leverage it, check it? (Belluci et al., 2020).

From the authors point of view, the enterprise intellectual resources become IC when they are managed strategically, e.g. supporting reaching strategic goals and implementation of generic strategies of company. Therefore, the authors have explored how different IMS application types that could be used for the intellectual resource's development as a necessary condition for development IC of organization.

\section{The Role of IMS in Intellectual Resources Development}

In open innovation perspective (Chesbrough, 2003; West, Salter, Vanhaverbeke, \& Chesbrough, 2014), firms attract knowledge from a wide range of external sources (Björk \& Magnusson, 2009; Laursen \& Salter, 2006; 2014). The external and mixed IMS are one of such importance sources. Innovation is the outcome of application of these knowledge turning them in patents or other IC (Cruz-González, López-Sáez, Navas-López, \& Delgado-Verde, 2015; Doloreux, 2004; Weitzman, 1998).

According to Open innovation theory (Alexy, Bascavusoglu-Moreau, \& Salter, 2016), a holistic cognitive approach should allow the company to exploit internal knowledge and use external knowledge in the dynamic environment (Giudice \& Maggioni, 2014; Ferraris, Santoro, \& Dezi, 2017; Santoro, Vrontis, Thrassou, \& Dezi, 2018). Both internal and external IMS are significant tools to attract and manage ideas for delivering licences, trade marks and patents. On the other hand, innovation has been defined as a tool that combines knowledge in new ways (Du Plessis, 2007), highlighting the potential of the organization's knowleadge to encourage development of innovations (Vaio, Palladino, Pezzi, \& Kalisz, 2020). The authors point of view is that innovation is not a tool itself but rather the result of recombination of existing and new knowledge in a new ways by exploiting existing and newly attracted resources.

Innovation development is a critical source of growth and profitability (Audretsch, Coad, \& Segarra, 2014) that has been traditionally associated with a firm's internal R\&D activities; however, more recently, firms are increasingly drawing knowledge and technologies from external sources (Chesbrough, West, \& Vanhaverbeke, 2006; Grimaldi, Greco, \& Cricelli).

\section{Research Methodology}

The survey was conducted on the survey platform „The QuestBack” in 2019. This survey results allowed to compile data on IMS in 8 blocks: (1) type of IMS; (2) tasks; (3) organization system; (4) adaptation and type of use; (5) IMS results; 
(6) organizational effectiveness; (7) new structures; (8) problems with the use of IMS. A total of 186 elements are summarized in 8 question blocks. In this paper applied the survey block - IMS results. The questionnaire was created and distributed in English, as the dominant language of the IMS and its use in English. It should be noted that in order to reach the target audience more accurately, the authors asked IMS developers to distribute the survey to their clients. It was stated that the survey should only be sent to companies using the system in question to the person in charge of the IMS. In the author private communication with 107 IMS developers and the information published by the IMS concerned, it was concluded that the IMS employs around 70000 - 120000 companies (derived from the average number of IMS clients). Survey distributed globally. Research aim is to clarify IMS perspectives from intellectual resources development side and thus improving innovation acceleration and to draw the theoretical conclusions on choosing and applying the most appropriate IMS approach in this area.

The following hypothesis statements have been tested:

H1: IMS application has resulted in new intellectual resources.

H2: IMS application has resulted in patents.

H3: IMS application has improved innovation acceleration.

Hypothesis testing approach is based on theoretical guidelines (Moore, McCabe, Alwan, \& Craig, 2016). For hypothesis testing the authors will use the proportion $\left(P_{\mathrm{i}}\right)$ of respondents who believe that the application of particular type of IMS has resulted in new intellectual resources:

$$
P_{i}=\frac{k_{i}}{n_{i}}
$$

where $k_{\mathrm{i}}$ - the number of respondents who believe that the application of particular type of IMS has resulted in new intellectual resources;

$n_{\mathrm{i}}$ - the number of respondents applying particular type of IMS.

Null and alternative hypothesis are defined as follows:

$$
H_{0}: P_{\mathrm{i}}-P_{\mathrm{j}} \leq 0 \text { and } H_{\mathrm{A}}: P_{\mathrm{i}}-P_{\mathrm{j}}>0
$$

As samples are simple random and independent, and $k>80 \&(n-k)>30$, the difference of two proportions follows an approximate normal distribution and test statistic is calculated as follows (Moore, 2016):

$$
z=\frac{P_{i}-P_{j}}{\sqrt{P_{c} *\left(1-P_{c}\right) *\left(\frac{1}{n_{i}}+\frac{1}{n_{j}}\right)}}
$$

where the pooled proportion $\left(P_{c}\right)$ is calculated as follows (Moore, 2016):

$$
P_{c}=\frac{k_{i}+k_{j}}{n_{i}+n_{M j}}
$$

Decision rule is to reject $H_{0}$ in favour of $H_{\mathrm{A}}$, if $z$-statistic $\left(z_{\text {stat }}\right)$ is larger than $z$-critical $\left(z_{\alpha}\right)$ values $(1,645)$ for $(\alpha=0,05)$ :

$$
z_{\text {stat }}>z_{\alpha}
$$

In Figure 1 see the distribution of respondents. 

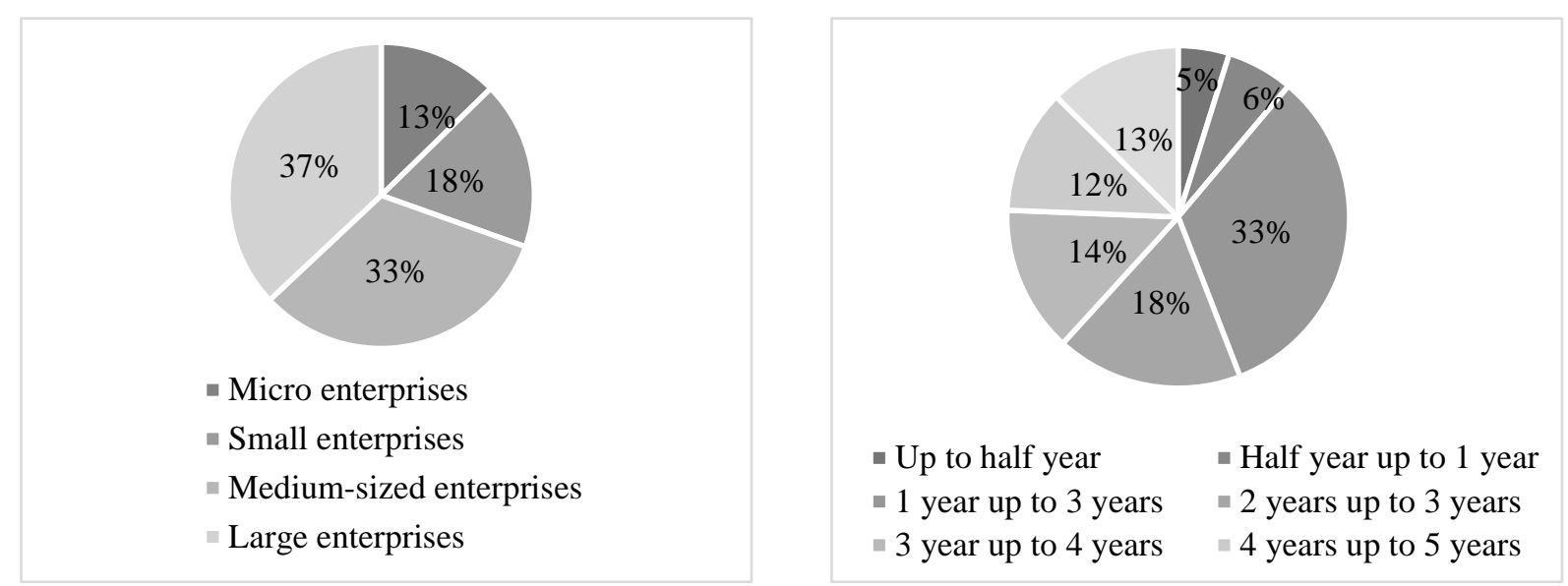

By enterprise size By years how long

Figure 1 Distribution of the Respondents (created by the authors)

\section{Findings of Hypothesis}

\section{Application of IMS types and new intellectual resources creation}

The results show the extent to which different IMS types has resulted in new intellectual resources, are summarized in the following Figure 2.

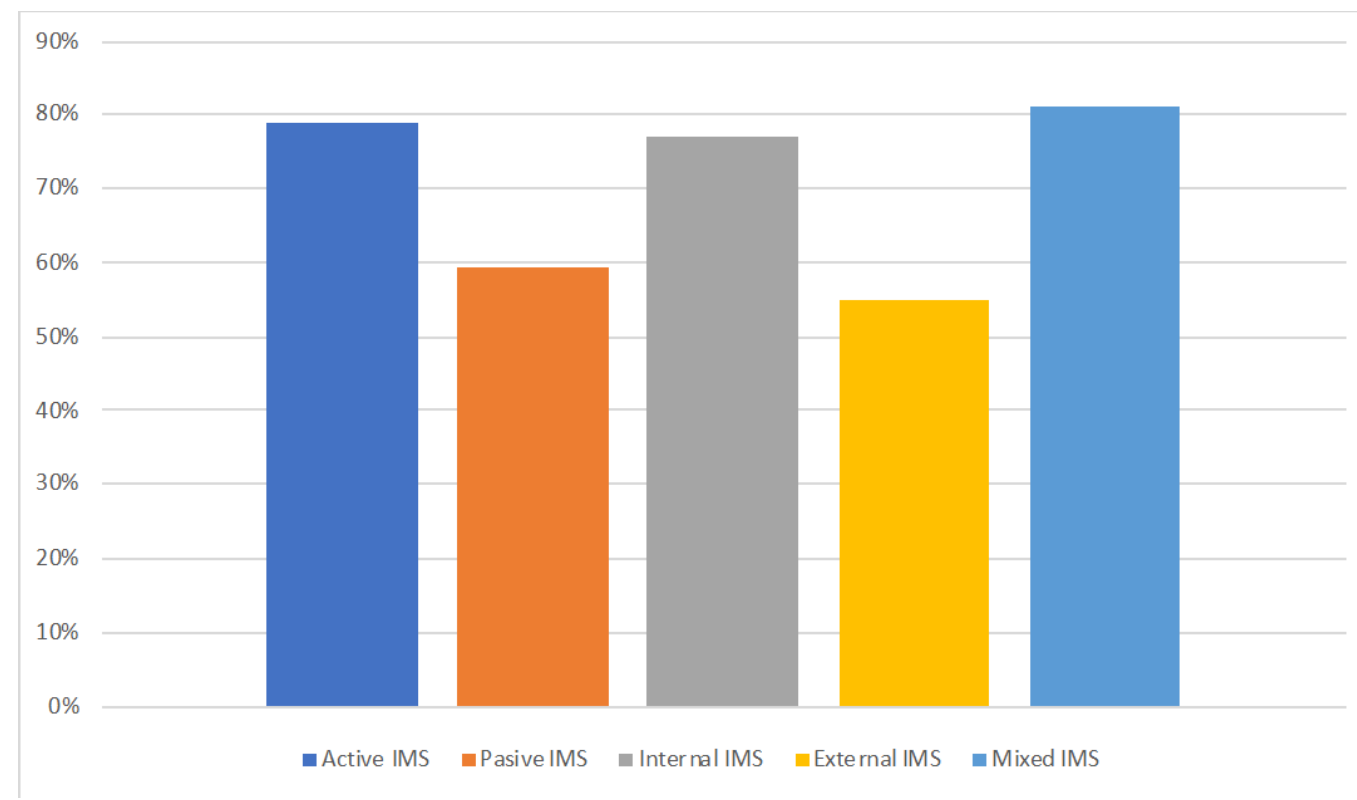

Figure 2 Proportion of Respondents Who Believe that Application of Particular IMS Type Has Resulted in New Intellectual Resources, \% (created by the authors)

Calculated proportions of respondents who believe that applications of particular IMS type has resulted in new intellectual resources, pooled proportions as well as $z$-statistics and corresponding $p$-values are summarized in following Table 2. 
SOCIETY. INTEGRATION. EDUCATION

Proceedings of the International Scientific Conference. Volume VI, May $28^{\text {th }}-29^{\text {th }}$, 2021. 400-412

Table 2 Statistics for Hypothesis Testing about Application of Different IMS Type and New Intellectual Resources Creation (created by the authors)

\begin{tabular}{|l|l|l|l|l|l|r|}
\hline \multicolumn{1}{|c|}{ IMS type } & $P_{i}$ & IMS type & $P_{i}$ & $P_{c}$ & $z_{\text {stat }}$ & $p$-value \\
\hline Active & 0,7874 & Passive & 0,5946 & 0,7292 & 4,9307 & $<0,001$ \\
\hline Internal & 0,7679 & External & 0,5485 & 0,6659 & 4,8829 & $<0,001$ \\
\hline Mixed & 0,8101 & Active & 0,7874 & 0,7959 & 0,7144 & 0,237 \\
\hline
\end{tabular}

As calculated z-statistics are larger than critical values for first two comparable IMS types pairs, authors would reject the corresponding null hypothesis and conclude that sample data provide strong evidence to support alternative hypothesis. Conclusions that application of active IMS has resulted in a new intellectual resource more than application of passive IMS and application of internal IMS has resulted in new intellectual resources more than application of external IMS is supported also by low $p$-value $(<0,001)$.

As calculated z-statistic isn't larger than critical values for the third comparable IMS types pairs, authors can't reject the corresponding null hypothesis and conclude that sample data do not provide enough evidence to support alternative hypothesis - the difference in the proportions of respondents who believe that application of mixed IMS type has resulted in new intellectual resources more than application of active IMS type isn't statistically significant.

\section{Application of different IMS types and new patents}

The results show the extent to which application of different IMS types has resulted in new patents, are summarized in the following Figure 3.

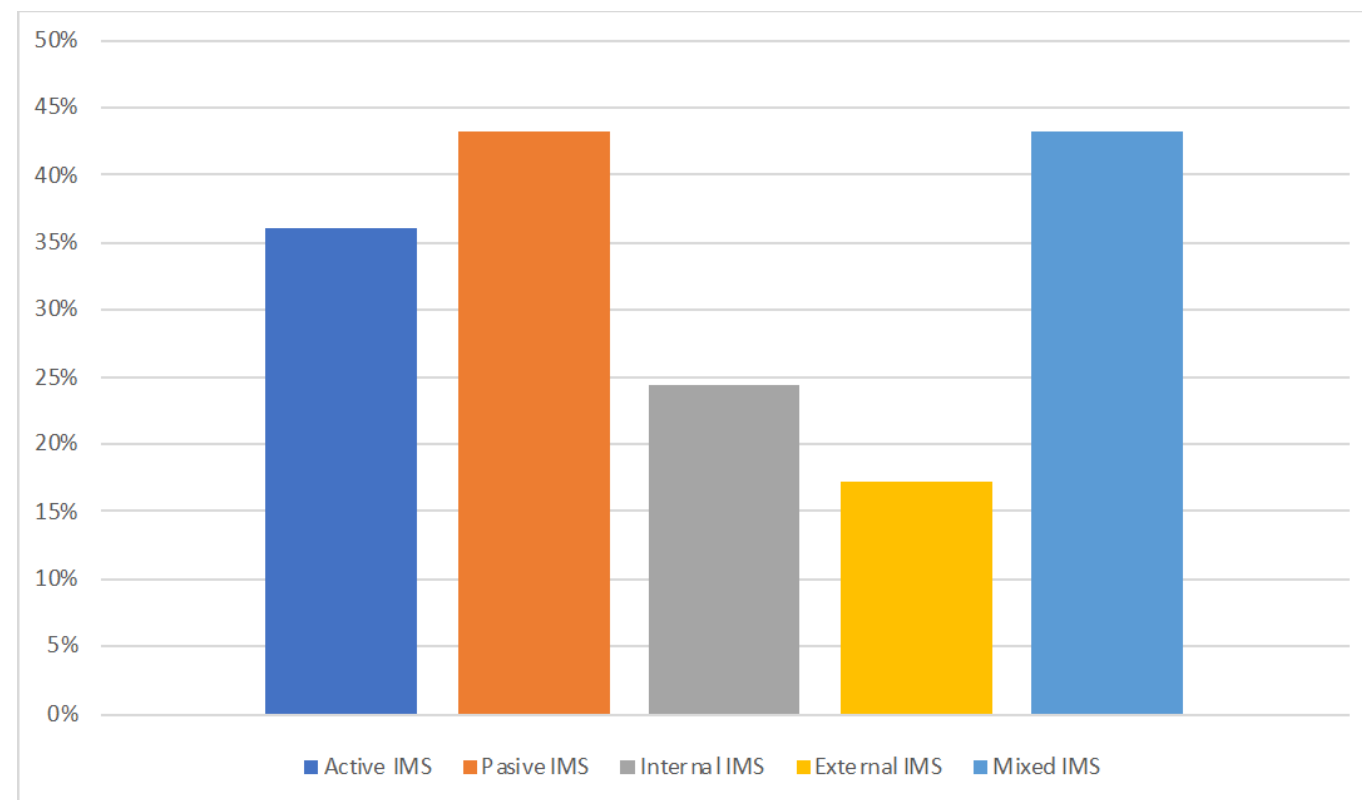

Figure 3 Proportion of Respondents Who Believe that Application of Particular IMS Type Has Resulted in New Patents, \% (created by the authors) 
Calculated proportions of respondents who believe that applications of particular IMS type have turned in new patents, pooled proportions as well as zstatistics and corresponding $p$-values are summarized in following Table 3.

Table 3 Statistics for Hypothesis Testing about Application of Different IMS Type and New Patents (created by the authors)

\begin{tabular}{|l|l|l|l|l|l|r|}
\hline \multicolumn{1}{|c|}{ IMS type } & $P_{i}$ & IMS type & $P_{j}$ & $P_{c}$ & $Z_{\text {stat }}$ & $p$-value \\
\hline Passive & 0,4324 & Active & 0,3598 & 0,3817 & 1,6989 & 0,045 \\
\hline Internal & 0,2437 & External & 0,1716 & 0,2104 & 1,8547 & 0,032 \\
\hline Mixed & 0,4319 & Active & 0,3598 & 0,3869 & 1,8758 & 0,030 \\
\hline Passive & 0,4324 & Mixed & 0,4319 & 0,4321 & 0,0110 & 0,496 \\
\hline
\end{tabular}

As calculated $z$-statistics are larger than critical values for first tree comparable IMS types pairs, authors would reject the corresponding null hypothesis and conclude that sample data provide strong evidence to support alternative hypothesis. Conclusions that application of passive IMS has resulted in new patents more than application of active IMS, application of internal IMS has resulted in new patents more than application of external IMS and application of mixed IMS has resulted in new patents more than application of active IMS is supported also by low $p$-value $(<0,045)$.

As calculated $z$-statistic isn't larger than critical values for the fourth comparable IMS type pairs, authors can't reject the corresponding null hypothesis and conclude that sample data do not provide enough evidence to support alternative hypothesis - the difference in the proportions of respondents who believe that application of passive IMS type has helped to achieve goals more than application of mixed IMS type isn't statistically significant.

\section{Application of different IMS types and innovation acceleration improvement}

The results of the survey, which show the extent to which different types of IMS has improved innovation acceleration, are summarized in the following Figure 4. 


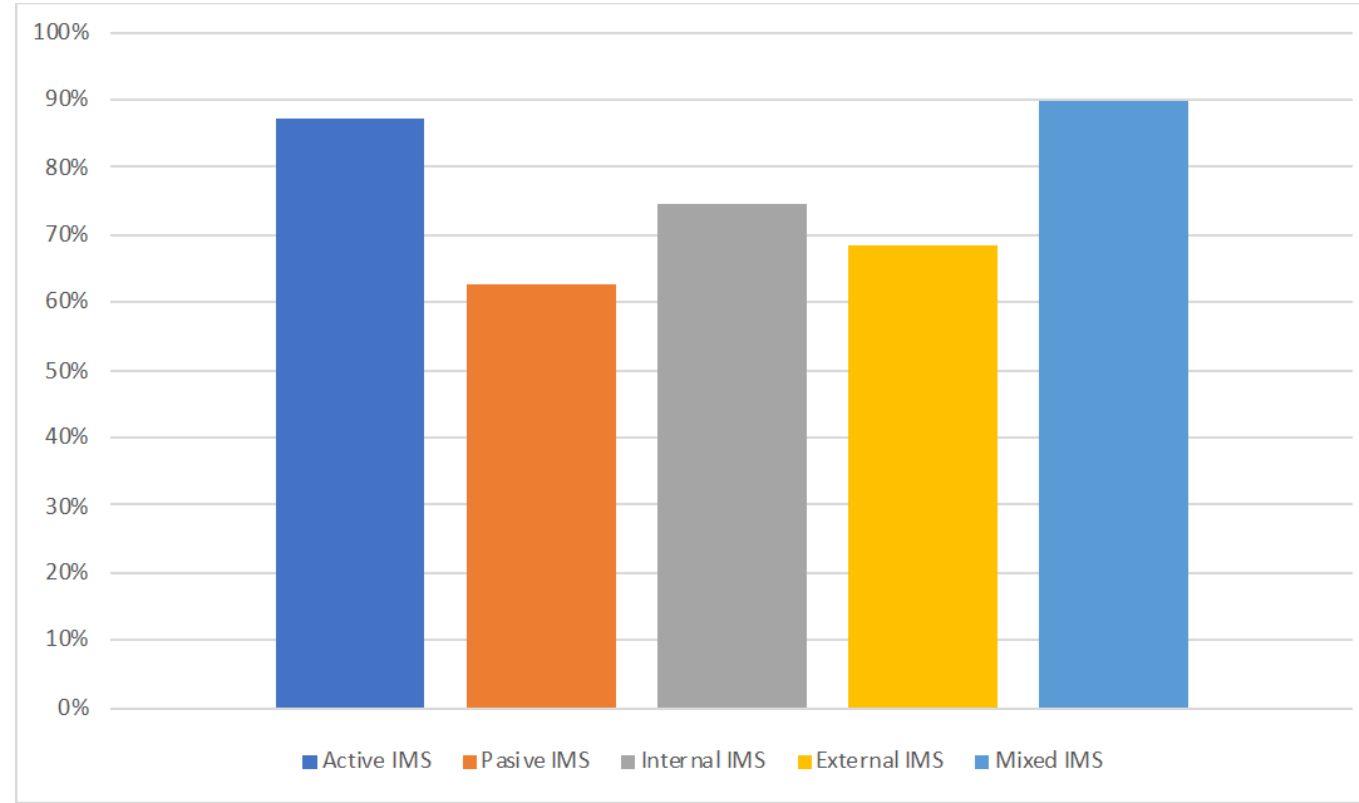

Figure 4 Proportion of Respondents Who Believe that Application of Particular IMS Type Has Improved Innovation Acceleration, \% (created by the authors)

Calculated proportions of respondents who believe that applications of particular IMS type has improved innovation acceleration, pooled proportions as well as $z$-statistics and corresponding $p$-values are summarized in following Table 4.

Table 4 Statistics for Hypothesis Testing about Application of Different IMS Type and Innovation Acceleration Improvement (created by the authors)

\begin{tabular}{|l|l|l|l|l|r|r|}
\hline \multicolumn{1}{|c|}{ IMS type } & $P_{i}$ & IMS type & $P_{j}$ & $P_{c}$ & $Z_{\text {stat }}$ & \multicolumn{1}{c|}{$p$-value } \\
\hline Active & 0,8712 & Passive & 0,6270 & 0,7974 & 6,9015 & $<0,001$ \\
\hline Internal & 0,7468 & External & 0,6863 & 0,7188 & 1,4105 & 0,079 \\
\hline Mixed & 0,8980 & Active & 0,8712 & 0,8812 & 1,0485 & 0,147 \\
\hline
\end{tabular}

As calculated $z$-statistics are larger than critical values for first comparable IMS type pairs, authors would reject the corresponding null hypothesis and conclude that sample data provide strong evidence to support alternative hypothesis. Conclusions that application of active IMS has improved innovation acceleration more than application of passive IMS is supported also by low $p$-value $(<0,001)$.

As calculated z-statistic isn't larger than critical values for the second and third comparable IMS type pairs, authors can't reject the corresponding null hypothesis and conclude that sample data do not provide enough evidence to support alternative hypothesis - the difference in the proportions of respondents who believe that application of internal IMS type has improved innovation 
acceleration more than application of external IMS type and application of mixed IMS type has improved innovation acceleration more than application of active IMS type isn’t statistically significant.

\section{Conclusions and Discussion}

The authors performed the research to identify how management mechanisms, in this case IMS, are contributing towards new intellectual resources development, including impact on generating patents and innovations.

From the authors point of view, the IMS has a complex nature. It is a management tool applied to foster delivering innovations and itself presents an intangible resource of the organization. This study offers a complementary interpretation of the relationships between the concept and theory of IMS and that new intellectual resources development, including ability to generate patents and deliver innovations based on the empirical study.

This study has several implications for enterprises as the research shows that the application of passive IMS has resulted in new patents more than application of active IMS, application of internal IMS has resulted in new patents more than application of external IMS and application of mixed IMS has resulted in new patents more than application of active IMS. The authors conclude that the application of active IMS has improved innovation acceleration more than application of passive IMS.

The authors agree with O'Cass and Sok that the intellectual resources serve as the basis to facilitate the product innovation process, so providing opportunities for achieving growth. But if they have poor intellectual resources, growth may be impacted (O’Cass \& Sok, 2013).

The authors research contributes to understanding that application of IMS is a valuable source for intellectual resources development and in the case when this process is managed strategically, company could create significant advantage over competitors, also through development IC of organization.

\section{Acknowledgment}

This paper was supported by the BA School of Business and Finance Internal Research Project 2021/1 "The allocation of Idea management systems in developing innovative entrepreneurship.” 
SOCIETY. INTEGRATION. EDUCATION

Proceedings of the International Scientific Conference. Volume VI, May $28^{\text {th }}-29^{\text {th }}$, 2021. 400-412

\section{References}

Alexy, O., Bascavusoglu-Moreau, J., \& Salter, A.J. (2016). Toward an aspiration-level theory of open innovation. Industrial and Corporate Change, 25 (2), 289-306. Retrieved from: https://academic.oup.com/icc/articleabstract/25/2/289/2357400?redirectedFrom=fulltext

Audretsch, D. B., Coad, A., \& Segarra, A. (2014). Firm growth and innovation. Small Business Economics, 43(4), 743-749. DOI: https://doi.org/10.1007/s11187-014-9560-x

Bellucci, M., Marzi, G., Orlando, B., \& Ciampi, F. (2020). Projects: Sustainability reporting, business models and non financial disclosure. Journal of Intellectual Capital: a review of emerging themes and future trends, Journal of Intellectual Capital, Vol. ahead-of-print No. ahead-of-print. DOI: https://doi.org//10.1108/JIC-10-2019-0239

Bertetta, M. (2015). The Role of Idea Management Systems for Innovation in Large Organizations: 3 essays, dissertation. School of Business and Social Sciences, Aarhus University.

Björk, J., \& Magnusson, M. (2009). Where Do Good Innovation Ideas Come From? Exploring the Influence of Network Connectivity on Innovation Idea Quality. Journal of Product Innovation Management, 26, 662-670. DOI: https://doi.org/10.1111/j.15405885.2009.00691.x

Bothos, E., Apostoulou, D., \& Mentzas, G. (2012). Collective intelligence with web-based information aggregation markets: The role of market facilitation in idea management. Experts Systems with Applications, 39(1), 1333-1345.

Buenechea-Elberdin, M. (2017). Deusto Business School, University of Deusto, Donostia-San Sebastián, Spain and School of Business and Management, Lappeenranta University of Technology, Lappeenranta, Finland. Journal of Intellectual Capital Vol. 18 No. 2, 262-285.

Chesbrough, H. (2003). Open Innovation: theNew Imperative for Creating and Profiting from Innovation. Cambridge, MA: Harvard Business School Press.

Chesbrough, H. (2006). Open business models: how to thrive in the new innovation landscape. Boston, MA: Harvard Business School Press.

Chesbrough, H. W., West, J., \&Vanhaverbeke, W. (2006). Open Innovation:Researching a New Paradigm. UK: Oxford University Press.

Chesbrough, H., \& Bogers, M. (2014). Clarifying an emerging paradigm for understanding innovation. In Chesbrough, H., Vanhaverbeke, W., \& West, J. (Ed.), New frontiers in open innovation (3-28). Oxford: Oxford University Press.

Chesbrough, H., Lettl, C., \& Ritter, T. (2018). Value Creation and Value Capture in Open Innovation. Journal of Product Innovation Management, 35(6), 930-938.

Cruz-González, J., López-Sáez, P., Navas-López, J.E., \& Delgado-Verde, M. (2015). Open search strategies and firm performance: The different moderating role of technological environmental dynamism. Technovation, 35, 32-45. DOI: https://doi.org/10.1016/ j.technovation.2014.09.001

Dahlander, L., \& D. M. Gann. (2010). How open is innovation? Research Policy, 39(6), 699-709.

Deichmann, D. (2012). Idea Management: Perspectives from Leadership, Learning, and Network Theory, dissertation. Netherland: ERIM. 
Doloreux, D. (2004). Regional networksof small and medium sized enterprises: evidence from the Metropolitan Area of Ottawa in Canada. European Planning Studies, 12 (2), 173-189. DOI: https://doi.org/10.1080/0965431042000183923

Du Plessis, M. (2007). The role of knowledge management ininnovation. Journal of Knowledge Management, 11 (4), 20-29. DOI: https://doi.org/10.1108/13673270710762684

Dumay, J., Rooney, J., \& Marini, L. (2013). An intellectual capital-based differentiation theory of innovation practice. Journal of Intellectual Capital, 14(4), 608-633.

Edvinsson, L., \& Malone, M. S. (1997). Intellectual Capital: Realizing Your Company’s True Value by Finding Its Hidden Brainpower. New York, NY:Harper Collins.

European Commission. (2006). RICARDIS: Reporting Intellectual Capital to Augment Research, Development and Innovation in SMEs. Brussels: European Commission. Directorate-General for Research.

Ferraris, A., Santoro, G., \& Dezi, L. (2017). How MNC's subsidiaries may improve their innovative performance?The role of external sourcesand knowledge management capabilities. Journal of Knowledge Management, 21 (3), 540-552. DOI: https://doi.org/10.1108/JKM-09-2016-0411

Galbraith, J. K. (1969). The New Industrial State. Harmondsworth, UK: Penguin.

Gassmann, O., Enkel, E., \& Chesbrough, H. (2010). The future of open innovation. $R \& D$ Management, 40 (3), 213- 221.

Giudice, M., \& Maggioni, V. (2014). Managerial practices and operative directions of knowledge management within inter-firm networks: A global view. Journal of Knowledge Management, 18 (5), 841-846. DOI: https://doi.org/10.1108/JKM-06-20140264

Grimaldi, M., Greco,M., \& Cricelli, L. (2021). A framework of intellectual property protection strategies and open innovation. Journal of Business Research, 123, 156-164.

Guertlerab, M.R., \& Sick, N. (2020). Exploring the enabling effects of project management for SMEs in adopting open innovation - A framework for partner search and selection in open innovation projects. International Journal of Project Management. DOI: https://doi.org/10.1016/j.ijproman.2020.06.007

Inkinen, H., Kianto, A., Vanhala, M., \& Ritala, P. (2014). In Proceedings of Intellectual capital and performance - Empirical findings from Finnish firms. Matera, Italy: International Forum on Knowledge Assets Dynamics(IFKAD).

Laursen, K., \& Salter, A. (2006). Open for innovation: the role of openness in explaining innovation performance among U.K. manufacturing firms. Strategic Management Journal, 27, 131-150. DOI: https://doi.org/10.1002/smj.507

Laursen, K., \& Salter, A. (2014). The paradox of openness: Appropriability, external search and collaboration. Research Policy, 43(5), 867-878. DOI: https://doi.org/10.1016/ j.respol.2013.10.004

Lerro, A., Linzalone, R., \& Schiuma, G. (2014). Managing intellectual capital dimensions for organisational value creation. Journal of Intellectual Capital, 15(3), 261-350.

Lyu, Y., Zhu, Y., Han, S., He, B., \& Bao, L. (2020). Open innovation and innovation "Radicalness" - the moderating effect of network embeddedness. Technology in Society, 62(1). DOI: https://doi.org/10.1016/j.techsoc.2020.101292

Lowe, M., \& Heller, J.E. (2014). PLM Reference Model for Integrated Idea and Innovation Management. Product Lifecycle Management for a Global Market. IFIP Advances in Information and Communication Technology, 442(1), 257-266.

Miḳelsone, E., Volkova, T., \& Lielā, E. (2019). Practical Evidence of Web-Based Idea Management Systems: Classification and Application. Inproceedings of the 25th 
SOCIETY. INTEGRATION. EDUCATION

Proceedings of the International Scientific Conference. Volume VI, May $28^{\text {th }}-29^{\text {th }}$, 2021. 400-412

International Scientific Conference "Research for Rural Development 2019”. Jelgava, Latvia University of Life Sciences and Technologies, 15th-17th May 2019.

Moore, D., McCabe, G., Alwan, L., \& Craig, B. (2016). The practice of statistics for business and economics. 4th ed. New York: W.H.Freeman \& Co.

O’Cass, A., \& Sok, P. (2013). The role of intellectual resources, product innovation capability, reputational resources and marketing capability combinations in firm growth. International Small Business Journal, 0(0), 1-23.

Santoro, G., Vrontis, D. , Thrassou, A., \& Dezi, L. (2018). The Internet of Things: Buildinga knowledge management system for open innovation and knowledge management capacity. Technological Forecasting and Social Change, 136, 347-354. DOI: 10.1016/j.techfore.2017.02.034

Selart, M., \& Johansen, S. T. (2011). Understanding the Role of Value - Focused Thinking in Idea Management. Creativity and Innovation Management, 20(3), 196-206.

Subramaniam, M., \& Youndt, M. (2005). The influence of intellectual capital on the types of innovative capabilities. Academy of Management Journal, 48 (3), 450-463.

Teece, D. J. (2007). Explicating dynamic capabilities: the nature and microfoundations of (sustainable) enterprise performance. Strategic Management Journal, 28 (13), 13191350.

Vaio, A. D., Palladino, R., Pezzi, A., \& Kalisz, D. E (2020). The role of digital innovation in knowledge management systems: A systematic literature review. Journal of Business Research, 123, 220-231. DOI: https://doi.org/10.1016/j.jbusres.2020.09.042

Weitzman, M. L. (1998). Recombinant Growth. The Quarterly Journal of Economics, 113, 331360. DOI: https://doi.org/10.1162/003355398555595

West, J., \& Bogers. M. (2014). Leveraging external sources of innovation: A review of research on open innovation. Journal of Product Innovation Management, 31(4), 814- 831.

West, J., Salter, A., Vanhaverbeke, W., \& Chesbrough, H. (2014). Open innovation: The next decade. Research Policy, 43 (5), 805-811. DOI: https://doi.org/10.1016/ j.respol.2014.03.001

Westerski, A. (2013). Semantic Technologies in Idea Management Systems: A Model for Interoperability, Linking and Filtering, dissertation. Madrid: Universidad Politecnica de Madrid.

Westerski, A., Dalamagas, T., \& Iglesias, C.A. (2013). Classifying and comparing community innovation in Idea Management Systems. Decision Support Systems, 54(1), 1316-1326.

Zhilenkova, E., Budanova, M., Bulkhov, N., \& Rodionov, D. (2019). Reproduction of intellectual capital in innovative digital economy environment. IOP Conference Series. Materials Science and Engineering, 497. DOI: htpps://doi.org/10.1088/1757899X/497/1/012065 